\title{
Penerapan Model Project Based Learning (PjBL) di SMAN 1 Muara Pahu Kelas XI pada Materi Fluida Statis
}

\author{
Tira Selviana Putri ${ }^{1 *}$, Muliati Syam², Laili Komariyah ${ }^{3}$ \\ 1,2,3 Program Studi Pendidikan Fisika Fakultas Keguruan dan IImu Pendidikan \\ Universitas Mulawarman, Samarinda-Indonesia \\ *E-mail: tiraselvianaputri@gmail.com
}

\begin{abstract}
Abstrak
Penelitian ini difokuskan pada penerapan model Project Based Learning (PjBL). Penelitian ini bertujuan untuk mengetahui aktivitas belajar, hasil belajar kognitif, dan respon peserta didik pada model Project Based Learning (PjBL). Jenis penelitian ini adalah penelitian kuantitatif dengan desain penelitian One Group Pre-test Post-test. Sampel yang digunakan sebanyak 31 peserta didik di kelas XI IPA SMAN 1 Muara Pahu. Instrumen yang digunakan adalah observasi, soal tertulis, dan angket. Berdasarkan penelitian, diperoleh bahwa persentase ratarata aktivitas belajar peserta didik sebesar $71 \%$ dan berada pada kategori baik. Nilai rata-rata pre-test hasil belajar kognitif peserta didik mendapatkan nilai sebesar 23 , sedangkan untuk nilai rata-rata post-test hasil belajar kognitif peserta didik mendapatkan nilai rata-rata sebesar 66 . Berdasarkan hasil analisis, respon peserta didik terhadap Project Based Learning ( $\mathrm{PJBL}$ ) mendapatkan nilai rata-rata sebesar 75,47 dan berada pada kategori baik.
\end{abstract}

Kata Kunci: Model Project Based Learning (PjBL), Aktivitas Belajar, Hasil Belajar Kognitif, Respon Peserta Didik

\begin{abstract}
The research is focused on the application of the Project Based Learning (PjBL). This research aims to determine learning activities, cognitive learning outcomes, and student responses to the Project Based Learning (PjBL) model. This type of research is quantitative research with One Group Pre-test Post-test research design. The sample used 31 students in class XI IPA of SMAN 1 Muara Pahu. The instruments used were observation, written questions, and questionnaires. Based on research, was found the average percentage of learning activities of students by $71 \%$ and in good category. The average value of pre-test cognitive learning outcomes of students get a value of 23, while for the average value of the post-test of cognitive learning outcomes of students get an average value of 66 . The results of the analysis, students' responses to Project Based Learning (PjBL) get an average value of 75.47 and in the good category.
\end{abstract}

Key Word : Project Based Learning (PjBL) Model, Learning Activities, Cognitive Learning Outcomes, Student Responses

$\begin{array}{lll}\text { Article History: } & \text { Received: } 5 \text { Agustus 2020 } & \text { Revised : 25 Agustus 2020 } \\ & \text { Accepted: } 7 \text { Agustus 2020 } & \text { Published: 20 November 2020 }\end{array}$

How to cite: Putri, T.S., Syam, M., Komariyah, L. (2020). Penerapan Model Project Based Learning (PjBL) di SMAN 1 Muara Pahu Kelas XI pada Materi Fluida Statia. Jurnal Pendidikan Fisika, 1(2). pp. 152 - 164. Retrieved from http://jurnal.fkip.unmul.ac.id/index.php/jpfp/index

Copyright (C) November 2020, Jurnal Literasi Pendidikan Fisika 


\section{PENDAHULUAN}

Berdasarkan laporan PISA (Programme for International Student Assesment) peringkat Indonesia berada di urutan 62 pada bidang Sains, 63 pada bidang matematika dan 64 pada bidang membaca di dunia (Ita, 2019). Sedangkan berdasarkan data UNESCO (The United Nations Education, Scientific, and Culture Organization), mengatakan bahwa Indonesia menduduki peringkat 101 di dunia dengan skor 0,603 . Hal ini menandakan hanya sebanyak $44 \%$ penduduk menuntaskan pendidikan menengah, sementara $11 \%$ murid gagal menuntaskan pendidikan atau keluar dari sekolah (Ali, 2018). Mengutip dari artikel m.cnnindonesia.com, asisten direktur jendral UNESCO Qian Tang pernah mengatakan bahwa kesenjangan mutu pendidikan menjadi kendala di banyak Negara, khususnya Indonesia. (Suastha, 2016).

Aktivitas adalah bagian penting dalam proses belajar. Hal ini akan mengubah sistem mendengar dan membaca yang pasif menjadi sebuah pencarian, pemilihan, dan pemahaman materi secara aktif. Orang akan mempelajari sesuatu dengan cepat ketika pembelajarannya bersifat interaktif. Pada umumnya orang akan belajar secara efektif dan efisien ketika dia memutuskan berapa banyak yang telah dikerjakannya, terutama pada peserta didik yang aktif dan memiliki tingkat pengetahuan yang lebih tinggi (Daryanto dan Mulyo, 2013).

Aktivitas dalam belajar dapat memberikan nilai tambah (added value) bagi peserta didik memiliki kesadaran untuk belajar, mencari pegalaman langsung mengalami sendiri, belajar dengan menurut minat dan kemampuannya, menumbuhkembangkan sikap disiplin, pembelajaran dilaksanakan secara kongkrit, dan menumbuhkembangkan sikap kooperatif dikalangan peserta didik (Suhana, 2014).

Pemerintah berupaya untuk meningkatkan aktivitas peserta didik dengan cara menerapkan kurikulum 2013 yang terdapat penilaian keteramilan peserta didik pada kompetensi inti IV (KI-4). Pada keterampilan ini peserta didik akan di dorong untuk menjadi lebih aktif. Proses pembelajaran haruslah mampu mengembangkan kemampuan peserta didik dalam mengetahui (C1), memahami (C2), mengaplikasikan (C3), menganalisis (C4), mengevaluasi (C5), dan membuat (C6). Proses pembelajaran hendaknya menyenangkan dan dapat memotivasi peserta didik untuk berpartisipasi aktif, serta memberi ruang untuk berkreasi. Salah satu model pembelajaran yang dapat mengembangkan aspek keterampilan peserta didik ini adalah model Project Based Learning (PjBL).

Menurut Thomas (dalam Fathurrohman, 2016) pembelajaran berbasis proyek mempunyai beberapa prinsip, yaitu (a) Terpusat (centrality), (b) pertanyaan pendorong/penuntun (driving question), (c) investigasi konstruktif (constructive investigation), (d) otonomi (autonomy), dan (e) realistis (realism).

Model Project Based Learning (PjBL) merupakan model pembelajaran yang memberikan kesempatan kepada guru untuk mengelola pembelajaran di kelas dengan melibatkan kerja proyek. Kerja proyek yang dimaksud adalah menyajikan tugas-tugas yang kompleks bagi peserta didik yang mampu membangkitkan minat belajar peserta didik, merangsang kemampuan dalam memecahkan masalah, membuat keputusan, melakukan kegiatan investigasi, serta memberikan kesempatan kepada peserta didik untuk bekerja secara mandiri (Priansa, 2015).

Menurut Purnomo (dalam Lawe, 2019), model Project Based Learning (PjBL) ialah sebuah pembelajaran inovatif, dan lebih menekankan pada belajar kontekstual melalui kegiatankegiatan yang komplek. Fokus pembelajaran pada prinsip dan konsep dari suatu disiplin ilmu, melibatkan siswa melakukan investigasi pemecahan masalah dan kegiatan-kegiatan tugas-tugas bermakna, memberi kesempatan pembelajar bekerja secara mandiri dalam mengontruksi pengetahuan mereka sendiri dan menghasilkan produk nyata.

Model Project Based Learning (PjBL) juga memiliki beberapa kelebihan, yaitu mempersiapkan peserta didik untuk mengahadapi kehidupan nyata dan terus berkembang, menghubungkan pembelajaran di sekolah dengan dunia nyata, meningkatkan kemampuan komunikasi dan sosial peserta didik, kemampuan memecahkan masalah, kemampuan untuk menggunakan dan mengelola informasi, serta dapat meningkatkan kepecayaan diri peserta didik (Priansa, 2015). 
Pengaruh Model Pembelajaran....

Hal inilah yang menyebabkan peneliti menggunakan model Project Based Learning (PjBL). Selain dapat meningkatkan aktivitas peserta didik, model Project Based Learning (PjBL) juga dapat meningkatkan hasil belajar kognitif peserta didik. Hal ini juga di dukung dengan hasil penelitian Lestari (2019) yang menyatakan bahwa model Project Based Learning ( $\mathrm{PjBL})$ dapat meningkatkan aktivitas belajar dan hasil belajar peserta didik.

Menurut Wulandari (2016), pembelajaran sains mengajak peserta didik untuk belajar merumuskan konsep berdasar fakta-fakta empiris di lapangan. Oleh karena itu, pendekatan yang digunakan dalam menyampaikan pembelajaran sains adalah memadukan antara pengalaman proses sains dan pemahaman produk sains dalam bentuk pengalaman langsung.

Pada hakekatnya, fisika merupakan kumpulan pengetahuan, cara berfikir, dan penyelidikan (eksperimen), penerapannya dalam pembelajaran harus mempertimbangkan model pembelajaran yang efektif dan efisien serta mampu membuat peserta didik tertarik dan termotivasi untuk mempelajari fisika (Yance, Ramli, dan Mufit:2013).

Menurut Purworini (dalam Asmi dan Hasan, 2017) permasalahan pada pembelajaran fisika yaitu siswa sangat bergantung pada guru sehingga tidak terbiasa melihat alternatif lain yang mungkin dapat digunakan dalam menyelesainkan masalah secara efektif.

Menurut Gunawan, Setiawan, dan Widyantoro (2013) beberapa konsep fisika termasuk konsep yang abstrak. Konsep yang abstrak ini yang menjadi salah satu penyebab peserta didik menjadi pasif disaat proses belajar mengajar. Anggapan bahwa mata pelajaran fisika itu rumit juga menyebabkan antusias peserta didik menurun. Kurangnya minat peserta didik terhadap mata pelajaran fisika menyebabkan hasil belajar peserta didik tidak optimal.

Menurut Karsumi (2012), fluida statis merupakan satu materi dalam pelajaran Fisika yang sangat banyak ditemukan dalam kehidupan sehari-hari, namun pada kenyataannya peserta didik masih kesulitan dalam memahami konsep dan memecahkan permasalahan yang timbul. Hal inilah yang mendasari peneliti untuk menggunakan materi fluida statis untuk penelitian. Diharapkan dengan menggunakan model Project Based Learning (PjBL) peserta didik akan lebih memahami konsep fisika tentang fluida statis dan dapat memecahkan berbagai permasalahan yang ada.

Pemilihan tempat penelitian berdasarkan pengalaman langsung dari peneliti. Dimana proses belajar mengajar di SMAN 1 Muara Pahu masih berpusat pada guru. Di SMAN 1 Muara pahu para peserta didik juga jarang untuk masuk laboratorium. Walaupun sudah terdapat laboratorium di sekolah tetapi nyatanya peserta didik jarang menggunakannya. Terdapat banyak alat-alat laboratorium yang hanya tersimpan baik di dalam lemari. Hal ini tentu sangat disayangkan, terutama untuk peserta didik. Dengan diadakannya penelitian di Muara Pahu, diharapkan dapat menarik minat peserta didik terhadap mata pelajaran fisika dan dapat memberikan pengalaman yang menyenangkan untuk peserta didik.

Berdasarkan penjelasan diatas, peneliti mengadakan penelitian yang berjudul "Penerapan Model Project Based Learning (PjBL) Di SMAN 1 Muara Pahu Kelas XI Pada Materi Fluida Statis".

\section{METODE}

Penelitian ini mengaplikasikan pendekatan penelitian kuantitatif dengan metode quasi eksprimen. Desain penelitian yang digunakan adalah One-Group Pre-test Post-test Design. Pada desain ini pre-test diberikan kepada peserta didik sebelum diberi perlakuan. Dengan demikian hasil perlakuan dapat diketahui lebih akurat, karena dapat membandingkan dengan keadaan sebelum dan setelah diberi perlakuan (Sugiyono, 2015). Setelah diberi perlakuan selama 4 kali pertemuan peserta didik diberi post-test. Pre-test dan post-test masing-masing terdiri dari 10 butir soal essay.

Tabel 1. Desain Penelitian One-Groupe Pre-test Post-test Design

\begin{tabular}{ccc}
\hline Pre-test & Treatment & Post-test \\
\hline $\mathrm{O}_{1}$ & $\mathrm{X}$ & $\mathrm{O}_{2}$ \\
\hline
\end{tabular}

Keterangan :

$\mathrm{O}_{1}$ : Nilai Pre-test (sebelum diberi perlakuan).

$\mathrm{O}_{2}$ : Nilai Post-test (setelah diberi perlakuan).

$X$ : Perlakuan yang diberikan oleh model

Project Based Learning (PjBL).

Selain soal pre-test dan post-test, peneliti 
juga menggunakan lembar observasi. Lembar observasi digunakan untuk mengamati kegiatan pembelajaran dan aktivitas peserta didik dalam kegiatan belajar mengajar. Selain itu juga dapat dikembangkan dengan lembar pengamatan pengelolaan kegiatan pembelajaran model pembelajaran terpadu (Trianto, 2012). Dierich (dalam Hanafiah, 2009) menyatakan, aktivitas belajar dibagi ke dalam delapan kelompok dan delapan kelompok ini akan dibagi menjadi 15 indikator yang digunakan oleh peneliti sebagai penilaian aktivitas peserta didik.

Teknik pengambilan sampel dalam penelitian ini adalah Purposive Sampling. Teknik purposive sampling ialah teknik dengan penentuan sampel dengan pertimbangan tertentu. Sampel penelitian ini ialah peserta didik di kelas XI IPA yang terdiri dari 31 peserta didik.

Dalam penelitian ini teknik pengumpulan data yang digunakan adalah sebagai berikut:

1. Observasi

Observasi adalah proses pengamatan dan pencatatan secara sistematis mengenai gejala atau hal-hal yang diteliti. Jenis observasi yang digunakan pada penelitian ini adalah observasi langsung/terbuka, yaitu pengamatan yang dilakukan terhadap gejala atau proses yang terjadi dan langsung diamati oleh observator pada pertemuan I, II, III, dan IV. Observer pada penelitian ini adalah guru mata pelajaran fisika yang akan menilai peserta didik berdasarkan indikator yang telah dibuat oleh peneliti.

Indikator aktivitas belajar peserta didik ialah terdiri dari 15 buah indikator yaitu: 1) Memperhatikan, 2) Bertanya, 3) Berdiskusi, 4) Mengemukakan Pendapat, 5) Mencatat, 6) Mempresentasikan, 7) Mendengarkan, 8) Merancang, 9) Menyusun, 10) Memecahkan masalah/sal, 11) Menentukan, 12) Memperbaiki, 13) Melakukan uji coba, 14) Menyimpulkan, dan 15) Bersemangat.

2. Tes Tertulis

Tes tertulis merupakan alat penilaian yang digunakan untuk menilai dan mengukur hasil belajar peserta didik dengan cara memberikan pertanyaan-pertanyaan yang diberikan kepada peserta didik. Soal pre-test dan post-test yang diberikan kepada peserta didik sebelum dan setelah diberikan perlakuan model Project Based Learning
(PjBL) berbentuk soal essay yang terdiri dari masing-masing 10 butir soal.

3. Angket

Angket yang digunakan dalam penelitian ini adalah angket skala Likert yang berbentuk rating-scale, dimana peserta didik menjawab pernyataan dengan pilihan Sangat Tidak Setuju (STS), Tidak Setuju (TS), Cukup Setuju (CS), Setuju (S), Sangat Setuju (SS). Angket ini digunakan untuk mengetahui respon peserta didik setelah diberikan perlakuan.

Teknik analisis data yang digunakan pada penelitian ini adalah tingkat keaktifan peserta didik, uji $\mathrm{N}$-Gain, uji t-berpasangan, dan tingkat respon peserta didik.

Aktivitas belajar peserta didik dapat dicari dengan menggunakan rumus sebagai berikut :

$$
\text { Presentase }=\frac{\text { Skor Perolehan }}{\text { Skor Maksimal }} \times 100 \%
$$

Dimana :

$\mathrm{P}=$ Angka presentase aktivitas peserta didik

$\mathrm{F}=$ Frekuensi yang sedang dicari

presentasenya

$\mathrm{N}=$ Number of cases (jumlah

frekuensi/banyaknya individu)

(Sudjana, 2013)

Hasil belajar kognitif peserta didik akan dianalisis menggunakan $\mathrm{N}$-Gain dan uji tberpasangan. $\mathrm{N}$-Gain menunjukkan peningkatan pemahaman atau penguasaan konsep peserta didik setelah pembelajaran yang telah dilakukan oleh guru. Pengujian dilakukan untuk aspek kognitif, yaitu dengan menggunakan rumus sebagai berikut :

$$
N-\text { Gain }=\frac{S_{\text {posttest }}-S_{\text {pretest }}}{S_{\text {maksimum }}-S_{\text {pretest }}}
$$

Keterangan :

$N-$ Gain : Keuntungan atau Peningkatan

Sost-test : Jumlah Skor Post-test

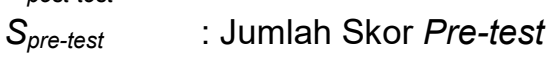

$S_{\text {maksimum }}$ : Jumlah Skor Maksimum

(Cahaya, 2017)

Tinggi rendahnya gain yang normalisasi $(N$ Gain) dapat dikategorikan sebagai berikut :

Tabel 2. Kriteria N-Gain

\begin{tabular}{cc}
\hline Nilai & Kategori \\
\hline $\mathrm{g}>0,7$ & Tinggi \\
\hline
\end{tabular}


Pengaruh Model Pembelajaran....

\begin{tabular}{cl}
\hline $0,3 \leq \mathrm{g}<0,7$ & Sedang \\
\hline $0 \leq \mathrm{g}<0,3$ & Rendah \\
\hline
\end{tabular}

Peneliti menggunakan Uji t-berpasangan untuk mengetahui pengaruh model Project Based Learning (PjBL) di SMAN 1 Muara Pahu terhadap data skor pre-test dan post-test pada kelas XI IPA. Pengujian uji-t perlu memperhatikan langkah-langkah sebagai berikut. Hipotesisnya adalah :

$$
H_{0}: \mu_{1}=\mu_{2}
$$

$H_{o} \quad$ : Tidak terdapat perbedaan yang signifikan antara model Project Based Leaning (PjBL) terhadap hasil belajar kognitif peserta didik.

$H_{a} \quad$ : Terdapat perbedaan yang signifikan antara model Project Based Leaning $(P j B L)$ terhadap hasil belajar kognitif peserta didik.

Secara sistematis dapat menggunakan rumus sebagai berikut :

$$
t=\frac{\overline{x d}-\mu}{S d / \sqrt{n}}
$$

(Riduwan, 2010)

Keterangan :

$$
\begin{array}{ll}
\mathrm{d} & =\text { Selisih } x_{1}-x_{2} \\
\mathrm{n} & =\text { Jumlah sampel } \\
\mathrm{xd} & =\text { Rata-rata deviasi } \\
\mathrm{Sd} & =\text { Standar deviasi dari } \mathrm{d} \\
\mu & =\text { Nilai rata-rata perbedaan deviasi }
\end{array}
$$

Pengujian melalui Uji-t dengan membandingkan t-hitung dengan t-tabel pada taraf nyata $\alpha=0,05$. Pengambilan keputusan pada uji-t berpasangan. Jika nilai probabilitas (thitung $>$ t-tabel) maka terdapat pengaruh yang signifikan antara model Project Based Leaning $(P j B L)$ terhadap hasil belajar kognitif peserta didik pada data pre-test dan post-test dengan probabilitas lebih kecil dari 5\% $(p<0,05)$. Sedangkan jika nilai probabilitas (t-hitung $<$ ttabel) maka tidak dapat pengaruh yang signifikan antara model Project Based Leaning (PjBL) terhadap hasil belajar peserta didik pada data pre-test dan post-test.

Data respon peserta didik diperoleh dari angket yang diedarkan kepada seluruh peserta didik setelah proses belajar mengajar selesai, tujuannya untuk mengetahui bagaimana respon peserta didik terhadap penggunaan model
Project Based Learing (PjBL). Data tersebut dianalisis dengan menggunakan persentase. Adapun rumus presentasenya adalah:

$\frac{\text { Jumlah respon siswa tiap aspek yang muncul }}{\text { Jumlah seluruh siswa }} \times 100 \%$

\section{HASIL DAN PEMBAHASAN}

\section{HASIL}

Penelitian ini dilaksanakan di SMAN 1 Muara Pahu yang terletak di jalan Bina Kampung, Desa Sebelang, Kecamatan Muara Pahu, Kabupaten Kutai Barat. Sampel dalam penelitian ini adalah peserta didik kelas XI IPA yang terdiri dari 33 orang, dengan jumlah peserta didik laki-laki 11 orang dan jumlah peserta didik perempuan 22 orang.

Pada pembelajaran ini, peserta didik dibagi menjadi 6 kelompok. Setiap kelompok terdiri dari 4-5 orang peserta didik yang heterogen. Peneliti memberikan waktu selama 2 minggu untuk peserta didik menyelesaikan proyek dan mempresentasikan proyek yang telah mereka kerjakan.

1. Aktivitas Belajar Peserta Didik

Pada pengumpulan data aktivitas belajar, peneliti menggunakan lembar observasi yang berbeda pada setiap pertemuan. Hal ini dikarenakan tahap pembelajaran dengan menggunakan model Project Based Learning $(\mathrm{PjBL})$ berbeda pada setiap pertemuannya. Sehingga aktivitas belajar peserta didik juga akan berbeda pada setiap pertemuan. Lembar observasi akan diisi oleh observer dengan memberikan skor 1 sampai 3 untuk tiap indikator dan sesuai dengan rubrik observasi yang telah ditentukan oleh peneliti. Setelah observer menilai peserta didik, setiap indikator akan di rata-ratakan pada setiap pertemuannya. Perubahan aktivitas belajar peserta didik akan terlihat dari hasil rata-rata aktivitas belajar pada setiap pertemuan. Nilai inilah yang akan peneliti ambil sebagai hasil dari aktivitas peserta didik. Sehingga akan terlihat apakah aktivitas peserta didik mengalami peningkatan atau penurunan.

Data pertemuan pertama aktivitas belajar peserta dapat dilihat pada tebel berikut ini: 
Pengaruh Model Pembelajaran....

Tabel 3. Aktivitas Belajar Peserta didik

\begin{tabular}{ccccc}
\hline \multirow{2}{*}{ Indikator } & $\begin{array}{c}\text { Pertemuan } \\
\text { Pertama }\end{array}$ & $\begin{array}{c}\text { Pertemuan } \\
\text { Kedua }\end{array}$ & $\begin{array}{c}\text { Pertemuan } \\
\text { Ketiga }\end{array}$ & $\begin{array}{c}\text { Pertemuan } \\
\text { Keempat }\end{array}$ \\
\cline { 2 - 6 } Memperhatikan & $89 \%$ & $89 \%$ & $89 \%$ & $82 \%$ \\
\hline Bertanya & $40 \%$ & $59 \%$ & $59 \%$ & $33 \%$ \\
\hline Berdiskusi & $100 \%$ & $100 \%$ & $100 \%$ & $63 \%$ \\
\hline $\begin{array}{c}\text { Mengemukakan } \\
\text { Pendapat/Pengalaman }\end{array}$ & $41 \%$ & $67 \%$ & $67 \%$ & $54 \%$ \\
\hline Mendengarkan & $89 \%$ & $89 \%$ & $89 \%$ & $74 \%$ \\
\hline Mencatat & $100 \%$ & $100 \%$ & $100 \%$ & - \\
\hline Mempresentasikan & - & $58 \%$ & $58 \%$ & $82 \%$ \\
\hline Merancang & $100 \%$ & - & - & - \\
\hline Menyusun & $67 \%$ & - & - & - \\
\hline Melakukan Uji Coba & - & - & - & $98 \%$ \\
\hline Memecahkan & $46 \%$ & $55 \%$ & $58 \%$ & - \\
\hline Masalah/soal & $100 \%$ & - & - & - \\
\hline Menentukan & - & - & - & $83 \%$ \\
\hline Menyimpulkan & - & $100 \%$ & $100 \%$ & - \\
\hline Memperbaiki & $67 \%$ & $68 \%$ & $100 \%$ & - \\
\hline Bersemangat & & & &
\end{tabular}

Berdasarkan hasil aktivitas belajar peserta didik dari pertemuan pertama hingga pertemuan keempat, dapat diperoleh hasil rata-rata aktivias belajar peserta didik yang dapat dilihat pada tabel berikut ini:

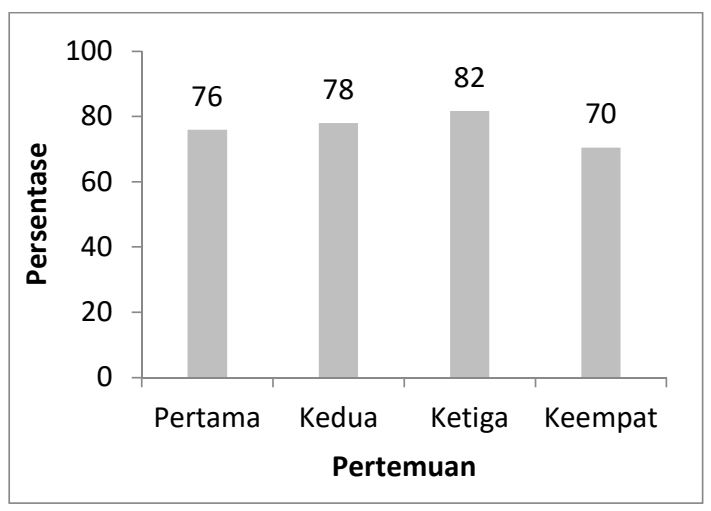

Gambar 1. Persentase Rata-rata Aktivitas Belajar Peserta Didik

2. Hasil Belajar Kognitif

a. Hasil Pre-test Peserta Didik

Pre-test dilakukan sebelum pembelajaran fisika menggunakan model Project Based Learning (PjBL) untuk mengetahui kemampuan awal peserta didik. Berdasarkan hasil analisis, diperoleh hasil skor rata-rata pre-test sebesar 23 dengan tingkat ketuntasan $100 \%$ belum tuntas.

Data tingkat keberhasilan pre-test peserta didik dapat dilihat pada tabel berikut ini :

Tabel 4. Hasil Pre-test Peserta Didik

\begin{tabular}{cccc}
\hline No & $\begin{array}{c}\text { Tingkat } \\
\text { Keberhasilan }\end{array}$ & Kriteria & Persentase \\
\hline 1 & $0 \%-20 \%$ & $\begin{array}{c}\text { Sangat } \\
\text { Rendah }\end{array}$ & $35 \%$ \\
\hline 2 & $21 \%-40 \%$ & Rendah & $61 \%$ \\
\hline 3 & $41 \%-60 \%$ & Cukup & $3 \%$ \\
\hline 4 & $61 \%-80 \%$ & Tinggi & $0 \%$ \\
\hline 5 & $81 \%-100 \%$ & $\begin{array}{c}\text { Sangat } \\
\text { Tinggi }\end{array}$ & $0 \%$ \\
\hline
\end{tabular}

b. Hasil Post-test Peserta Didik

Post-test dilakukan setelah pembelajaran fisika menggunakan model Project Based Learning (PjBL). Berdasarkan hasil analisis, di peroleh nilai rata-rata post-test sebesar 66. Terdapat 17 peserta didik yang belum tuntas dan terdapat 14 peserta didik. 
Pengaruh Model Pembelajaran....

Data ketuntasan peserta didik dapat dilihat secara rinci melalui tingkat keberhasilan belajar peserta didik. Data tingkat keberhasilan post-test peserta didik dapat dilihat pada grafik berikut ini:

Tabel 5. Hasil Post-test Peserta Didik

\begin{tabular}{cccc}
\hline No & $\begin{array}{c}\text { Tingkat } \\
\text { Keberhasilan }\end{array}$ & Kriteria & Persentase \\
\hline 1 & $0 \%-20 \%$ & $\begin{array}{c}\text { Sangat } \\
\text { Rendah }\end{array}$ & $0 \%$ \\
\hline 2 & $21 \%-40 \%$ & Rendah & $13 \%$ \\
\hline 3 & $41 \%-60 \%$ & Cukup & $26 \%$ \\
\hline 4 & $61 \%-80 \%$ & Tinggi & $39 \%$ \\
\hline 5 & $81 \%-100 \%$ & $\begin{array}{c}\text { Sangat } \\
\text { Tinggi }\end{array}$ & $23 \%$ \\
\hline
\end{tabular}

\section{c. Uji N-Gain Peserta Didik}

Data uji $\mathrm{N}$-Gain di dapatkan dari membandingkan hasil pre-test dan posttest hasil belajar peserta didik. Data peningkatan hasil belajar peserta didik dapat dilihat pada tabel berikut:

Tabel 6. Persentase Peningkatan Hasil Belajar Peserta Didik

\begin{tabular}{cccc}
\hline No & Rentang & Kriteria & Persentase \\
\hline 1 & $N$-gain $\geq 0,7$ & Tinggi & $29 \%$ \\
\hline 2 & $\begin{array}{c}0,3 \leq N- \\
\text { Gain } \leq 0,7\end{array}$ & Sedang & $58 \%$ \\
\hline 3 & $N$-gain $<0,3$ & Rendah & $13 \%$ \\
\hline
\end{tabular}

d. Uji t-berpasangan

Data hasil pre-test dan post-test hasil belajar peserta didik juga digunakan untuk menguji hipotesis. Pengujian hipotesis ini dilakukan dengan menghitung t-tabel dan t-hitung menggunakan SPSS 23. Hasil yang diperoleh dapat dilihat pada tebel berikut ini:

Tabel 7. Hasil Uji t-berpasangan Menggunakan SPSS 23

\begin{tabular}{cccc}
\hline & t-hitung & t-tabel & $\begin{array}{c}\text { Sig. } \\
\mathbf{2 - T a i l e d} \\
\text { (P) }\end{array}$ \\
\hline $\begin{array}{c}\text { Pre-test } \\
\text { Post-test }\end{array}$ & 13,516 & 1,69726 & 0,000 \\
\hline
\end{tabular}

Berdasarkan tabel diatas, dapat diketahui bahwa nilai signifikasi yang diperoleh adalah 0,000 dan nilai t-hitung 13,516. Nilai t-tabel dengan df 30 dengan taraf signifikasi 0,05 memiliki nilai 1,69726. Jadi, nilai t-hitung > t-tabel. Hal ini berarti bahwa terdapat pengaruh yang signifikan antara model Project Based Learning (PjBL) terhadap hasil belajar kognitif peserta didik.

\section{Respon Peserta Didik}

Data hasil analisis respon peserta didik diperoleh dari angket yang diberikan kepada peserta didik setelah proses belajar mengajar selesai. Angket ini akan diisi sendiri oleh peserta didik sendiri dengan memberikan pilihan sangat tidak setuju (STS), tidak setuju (TS), cukup setuju (CS), setuju (S), dan sangat setuju (SS). Berdasarkan hasil analisis, data respon peserta didik yang diperoleh dapat dilihat pada tabel berikut ini:

Tabel 8. Hasil Respon Peserta Didik

\begin{tabular}{ccc}
\hline Indikator & Persentase & Kategori \\
\hline Minat & $80 \%$ & Baik \\
\hline $\begin{array}{c}\text { Tahap } \\
\text { pembelajaran }\end{array}$ & $76 \%$ & Baik \\
\hline $\begin{array}{c}\text { Isi dan Desain } \\
\text { LKPd }\end{array}$ & $77 \%$ & Baik \\
\hline $\begin{array}{c}\text { Pembelajaran } \\
\text { dengan PjBL }\end{array}$ & $79 \%$ & Baik \\
\hline $\begin{array}{c}\text { Kerjasama } \\
\text { Kelompok }\end{array}$ & $86 \%$ & Baik Sekali \\
\hline Rata-rata & $80 \%$ & Baik \\
\hline
\end{tabular}

\section{PEMBAHASAN}

1. Aktivitas Belajar Peserta Didik

Selama kegiatan pembelajaran, peneliti dibantu oleh observer yang melakukan observasi terhadap aktivitas belajar peserta didik selama kegiatan pembelajaran. Kegiatan observasi dilakukan dengan cara memberi skor antara 1 sampai 3 pada lembar observasi tersebut. Pada lembar observasi tersebut terdapat 15 indikator pengamatan aktivitas belajar peserta didik..

Pada pertemuan pertama, terdapat 11 indikator aktivitas belajar yang digunakan. Berdasarkan hasil observasi aktivitas belajar peserta didik yang terdapat pada tabel 3 , rata-rata aktivitas belajar peserta didik adalah $76 \%$ yang berada pada kriteria baik. Walaupun demikian, masih ada dua indikator aktivitas belajar yang berada pada kategori 
sangat kurang yaitu aktivitas bertanya (40\%) dan mengemukakan pendapat $(41 \%)$. Sedangkan untuk aktivitas belajar yang berada pada kategori sangat baik ialah pada aktivitas memperhatikan (89\%), berdiskusi $(100 \%)$, mendengarkan $(89 \%)$, mencatat $(100 \%)$, merancang $(100 \%)$, dan menentukan (100\%). Berdasarkan pada hasil observasi ini kita ketahui bahwa walaupun peserta didik memperhatikan proses belajar mengajar namun masih banyak peserta didik yang masih belum berani atau malu untuk mengemukakan pendapat dan bertanya kepada guru. Namun, peserta didik sangat aktif berdiskusi bersama teman sekelompoknya. Hal ini berarti bahwa peserta didik lebih mudah untuk berinteraksi bersama teman sekelompoknya dibandingkan kepada guru. Hal ini dapat dipahami dikarenakan pada saat itu, peserta didik dan peneliti baru berinteraksi. Sehingga wajar saja apabila peserta didik masih belum dapat terbuka terhadap peneliti. Pada saat pertemuan pertama, tahap pembelajaran model Project Based Learning (PjBL) juga banyak menuntut peserta didik untuk berdiskusi bersama teman sekelompok untuk menyusun dan merancang proyek. Sehingga hasil aktivitas belajar pesera didik yang diperoleh bisa dianggap cukup baik.

Pada pertemuan kedua, terdapat 10 indikator aktivitas belajar yang digunakan. Berdasarkan hasil observasi aktivitas belajar peserta didik yang terdapat pada tabel 3 , rata-rata aktivitas belajar peserta didik adalah $78 \%$ yang berada pada kriteria baik. Rata-rata aktivitas belajar peserta ini mengalami peningkatan dibandingan pada saat pertemuan pertama. Hal ini disebabkan oleh aktivitas bertanya dan mengemukakan pendapat mengalami peningkatan, yang mana aktivitas bertanya menjadi $59 \%$ dan mengemukakan pendapat $67 \%$. Walaupun aktivitas bertanya masih berada pada kategori kurang dan mengemukakan pendapat berada pada kategori cukup namun hal ini sudah cukup membaik jika dibandingkan dengan pertemuan pertama. Hal ini menandakan bahwa peserta didik sudah mulai merasa nyaman pada saat bersama dengan guru. Walaupun demikian, pada aktivitas mempresentasekan (58\%) dan memecahkan masalah/soal (55\%) peserta didik masih berada pada kategori kurang. $\mathrm{Hal}$ ini dikarenakan walaupun peserta didik sudah mulai berani untuk mengemukakan pendapat dan bertanya kepada guru, peserta didik masih belum berani berdiri di depan kelas untuk mempresentasikan kemajuan proyek/percobaan dan menyelesaian contoh soal yang diberikan oleh guru.

Pada pertemuan ketiga, terdapat 10 indikator aktivitas belajar yang digunakan. Berdasarkan hasil observasi aktivitas belajar peserta didik yang terdapat pada tabel 3 , rata-rata aktivitas belajar peserta didik adalah $82 \%$ yang berada pada kriteria sangat baik. Hal ini dikarenakan pada pertemuan ketiga peserta didik melakukan percobaan atau membuat produk. Sehingga aktivitas berdiskusi, mencatat, memperbaiki, dan bersemangat peserta didik berada pada titik masimal yaitu $100 \%$. Walaupun demikian, untuk aktivitas mempresentaikan dan memecahkan masalah/soal peserta didik tidak berbeda dibandingkan pada saat pertemuan kedua.

Pada pertemuan keempat, terdapat 10 indikator aktivitas belajar yang digunakan. Berdasarkan hasil observasi aktivitas belajar peserta didik yang terdapat pada tabel 3 , rata-rata aktivitas belajar peserta didik adalah $70 \%$ yang berada pada kriteria baik. Hal ini menandakan bahwa pada pertemuan keempat aktivitas peserta didik mengalami penurunan jika dibandingkan dengan pertemuan-pertemuan sebelumnya. Hal ini dikarenakan pada saat peserta didik melakukan presentasi tidak terjadi tanyajawab antar peserta didik, yang mana presentase pada aktivitas bertanya adalah $33 \%$ dan pada aktivitas menjawab adalah $52 \%$. Penurunan hasil ini dikarenakan waktu pembelajaran yang terbatas. Sehingga setiap kelompok hanya diberikan waktu untuk mempresentasikan proyek yang telah mereka buat tanpa adanya diskusi mendalam kepada kelompok lain. Selain itu, pada aktivitas mengemukakan pengalaman peserta didik juga berada pada kategori kurang yang mana persentasenya hanya $54 \%$. Hal ini dikarenakan tidak semua peserta didik yang mengemukakan pengalamannya pada saat pembelajaran 
dengan menggunakan model Project Based Learning ( $\mathrm{PjBL})$. Hal ini juga dikarenakan waktu pembelajaran yang terbatas. Apabila setiap peserta didik mengemukakan pengalaman selama belajar menggunakan model Project Based Learning (PjBL) dikhawatirkan tidak akan terdapat cukup waktu. Namun, walaupun pada pertemuan keempat ini terdapat penurun tetapi setelah dirata-ratakan aktivitas belajar peserta didik masih berada pada kategori baik.

Berdasarkan hasil observasi, analisa persentase rata-rata aktivitas belajar peserta didik selama pembelajaran fisika mengunakan model Project Based Learning (PjBL) mendapatkan hasil sebesar $71 \%$. Apabila persentase aktivitas belajar peserta didik tersebut disesuaikan dengan skala rating aktivitas belajar peserta didik, maka aktivitas tersebut termasuk pada kriteria baik yang artinya aktivitas belajar peserta didik termasuk aktif.

Hal ini disebabkan karena dalam pembelajaran dengan mengunakan model model Project Based Learning (PjBL) peserta didik dituntut untuk aktif dalam setiap kegiatan pembelajaran menurut aspek aktivitas belajar yang diamati oleh observator.

Secara keseluruhan kegiatan pembelajaran dengan menggunakan model Project Based Learning (PjBL) telah mampu meningkatkan aktivitas peserta didik terutama dalam memperoleh pengalaman baru melalui keterlibatan peserta didik dalam kegiatan praktikum atau membuat sebuah produk.

Peningkatan aktivitas peserta didik juga berpengaruh terhadap hasil belajar peserta didik, sebab dalam proses pembelajaran yang menjadi pusatnya adalah peserta didik, maka aktivitas peserta didik merupakan salah satu syarat bagi berlangsungnya interaksi belajar mengajar. Aktivitas peserta didik dalam hal ini, baik secara fisik maupun secara mental aktif. Jadi tidak ada gunanya guru melakukan kegiatan belajar-mengajar jika siswa hanya pasif saja. Sebab, para peserta didiklah yang belajar, jadi merekalah yang harus melakukannya.

Sesuai dengan keunggulan dari pembelajaran dengan menggunakan model
Project Based Learning (PjBL), kemampuan komunikasi dan pemecahan masalah serta kepercayaan diri peserta didik mengalami peningkatan. Hal ini dapat dilihat pada saat pertemuan kedua dan ketiga dengan menggunakan model Project Based Learning (PjBL) di aktivitas bertanya dan menemukakan pendapat peserta didik yang mengalami peningkatan. Hal ini disebabkan karena tingginya tingkat aktivitas menunjukkan bahwa peserta didik lebih bersemangat dan termotivasi untuk belajar.

Hal ini sesuai dengan hasil penelitian Silaresmi, Saputro, dan Utomo (2017) yang pada penelitiannya menyatakan bahwa model Project Based Learning (PjBL) dapat meningkatkan aktivitas belajar peserta didik. Penelitian dari Dwi Ariani, Addiin, dan Redjeki (2014) juga mendapatkan hasil bahwa dengan menggunakan model Project Based Learning (PjBL) aktivitas peserta didik berada pada kriteria tinggi. Selain itu, hasil ini juga sesuai dengan pendapat Railsbach (dalam Priansa: 2015) yang mengatakan bahwa salah satu kelebihan model Project Based Learning ( $\mathrm{PjBL}$ ) adalah meningkatkan kemampuan komunikasi peserta didik dan meningkatkan kepercayaan diri peserta didik. Hal ini juga dikarenakan pada model Project Based Learning (PjBL) pembelajaran berpusat pada peserta didik. Model Project Based Learning (PjBL) juga memasukkan aktivitas sikap, perasaan, dan emosi sebagai komponen pembelajaran, sehingga membuat peserta didik lebih bersemangat dan berpartisipasi aktif dalam mengikuti kegiatan pembelajaran.

\section{Hasil Belajar Kognitif}

Pada pertemuan pertama, guru meminta peserta didik untuk mengerjakan soal pretest yang terdapat 10 butir soal. Berdasarkan hasil analisis, rata-rata persentase ketuntasan peserta didik adalah $100 \%$ tidak tuntas. Hal ini berarti bahwa semua peserta didik mendapatkan nilai dibawah 70 , karena nilai ketuntasan untuk mata pelajaran fisika yang berlaku di SMAN 1 Muara Pahu adalah 70. Dengan rincian data 1 orang berada pada kategori cukup, 19 orang berada pada kategori rendah, dan 11 orang berada pada kategori sangat rendah. Hal ini wajar terjadi, 
karena pada saat itu peserta didik belum belajar materi tentang fluida statis. Hal inilah yang menjadi tujuan peneliti menggunakan pre-test kepada peserta didik. Peneliti ingin mengetahui kemampuan awal setiap individu agar data yang diperoleh juga akan semakin baik.

Pada pertemuan terakhir, guru meminta peserta didik untuk mengerjakan soal posttest yang terdiri dari 10 butir soal essay. Pemberian soal post-test ini untuk mengetahui apakah setiap individu mengalami peningkatan atau penurunan jika dibandingkan dengan hasil pre-test peserta didik. Berdasarkan data yang diperoleh, 17 orang dari 31 peserta didik berada pada kategori belum tuntas sehingga persentasenya adalah $55 \%$ dan peserta didik yang tuntas terdapat 14 peserta didik dengan persentase $45 \%$. Dengan rincian, 4 orang berada pada kategori rendah, 8 orang berada paa kategori cukup, 12 orang berada pada kategori tinggi, dan 7 orang berada pada kategori sangat tinggi. Hal ini menandakan bahwa terdapat peningkatan hasil belajar peserta didik jika dibandingkan dengan hasil pre-test peserta didik. Hal ini umum terjadi dikarenakan peserta didik sudah mempelajari materi tentang fluida statis. Walaupun ada beberapa peserta didik yang masih berada pada kategori rendah, tetapi jika dibandingkan dengan hasil pretest, peserta didik tetap mengalami peningkatan hasil belajar walaupun nilai peningkatan ini sangat sedikit.

Berdasarkan data post-test yang diperoleh ini, dapat diketahui bahwa terdapat peningkatan hasil belajar pesera didik. Hasil peningkatan hasil belajar ini dengan rincian 4 orang peserta didik dengan kategori rendah, 18 orang peserta didik dengan kategori sedang, dan 9 orang peserta didik dengan kategori tinggi. Hal ini dapat diketahui dengan nilai $\mathrm{N}-\mathrm{Gain}$ yang terdapat pada tabel 6 .

Peningkatan hasil belajar ini disebabkan karena penggunaan mode Project Based Learning (PjBL) yang mana pada langkah pembelajarannya berpusat pada peserta didik. Penggunaan model ini mengharuskan peserta didik untuk merancang sendiri sebuah percobaan atau membuat sebuah produk sendiri. Pada langkah ini peserta didik mencari sendiri permasalahan yang ada dan belajar untuk menyelesaikan masalah sendiri. Hal ini menyebabkan kemampuan berpikir kritis peserta didik meningkat dan mendapatkan pengetahuan dengan sendirinya. Hal ini juga sesuai dengan pendapat beberapa pakar yang mengatakan bahwa salah satu kelebihan model Project Based Learning (PjBL) ini adalah dapat meningkatkan kemampuan pemecahan masalah peserta didik. Pemecahan masalah yang dimaksud disini ialah soal-soal hitungan yang diberikan oleh peneliti dalam soal pre-test dan post-test. Hal ini dapat dilihat dari banyaknya peserta didik yang menjawab pada soal post-test daripada soal pre-test. Hal ini juga menandakan bahwa model Project Based Learning (PjBL) memberikan pengaruh yang baik terhadap aktivitas dan hasil belajar peserta didik.

Setelah data pre-test dan post-test di analisis menggunakan SPSS 23, diperoleh hasil signifikan 2-tailed sebesar 0,000 yang berarti bahwa pada penelitian ini model Project Based Learning (PjBL) memiliki pengaruh yang signifikan terhadap hasil belajar kognitif peserta didik. Selain dari hasil signifikan 2-tailed, kita juga dapat menguji uji-t berpasangan dengan mencari nilai $\mathrm{t}$ hitung dan t-tabel. Berdasarkan data yang diperoleh oleh SPSS 23, diketahui bahwa nilai uji t-hitung adalah 13,516 dan berdasarkan tabel df 30 dengan signifikasi 0,05 memiliki nilai t-tabel sebesar 1,69725. Jadi, karena nilai t-hitung lebih besar dibandingkan t-tabel (t-hitung > t-tabel) maka dapat dikatakan bahwa terdapat pengaruh yang signifikan antara model Project Based Learning (PjBL) terhadap hasil belajar kognitif peserta didik dan Ho ditolak.

Hal ini dikarenakan pada model Project Based Learning (PjBL), peserta didik diwajibkan untuk aktif secara individu. Walaupun tugas untuk membuat proyek adalah kelompok, tetapi juga terdapat penilaian aktivitas individu. Keaktifan peserta didik inilah yang membuat hasil belajar peserta didik juga ikut meningkat. Peserta didik tidak lagi bergantung terhadap teman sekelas dan belajar untuk membuat dan menyelesaikan sendiri masalah yang ada. 
Hal ini memberikan peserta didik pengalaman baru dan hal ini menyebabkan peserta didik lebih mudah untuk mengingat materi dibandingkan dengan guru yang menjelaskan di depan kelas. Hal inilah salah satu keunggulan dalam menggunakan model Project Based Learning (PjBL) seperti yang dikatakan oleh Fathurrahman (2016).

Hal ini juga sesuai dengan hasil penelitian Silaresmi, Saputro, dan Utomo (2017) yang pada penelitiannya menyatakan bahwa model Project Based Learning (PjBL) dapat meningkatkan prestasi belajar peserta didik. Penelitian dari Dwi Ariani, Addiin, dan Redjeki (2014) juga mendapatkan hasil bahwa dengan menggunakan model Project Based Learning (PjBL) dapat meningkatkan hasil belajar peserta didik. Selain itu, penelitian dari Dwi, Prihandono, Subiki (2017) juga mendapatkan hasil bahwa model Project Based Learning (PjBL) mempunyai pengaruh yang signifikan terhadap hasil belajar kognitif peserta didik

\section{Respon Peserta Didik}

Pada akhir pembelajaran, peneliti memberikan angket kepada peserta didik. Penyebaran angket ini bertujuan untuk mengetahui respon peserta didik setelah diajar dengan menggunakan model Project Based Learning (PjBL). Angket yang digunakan dalam penelitian ini adalah angket skala Likert yang berbentuk rating-scale, dimana peserta didik menjawab pernyataan dengan pilihan sangat tidak setuju (STS), tidak setuju (TS), cukup setuju (CS), setuju (S), dan sangat setuju (SS). Angket ini terdiri dari 20 pernyataan dengan 5 indikator. Setiap indikator memiliki pernyataan positif dan pernyataan negatif.

Berdasarkan tabel 8, diketahui bahwa respon peserta didik yang paling rendah berada pada indikator tahap pembelajaran dengan persentase $76 \%$. Walaupun deminikian indikator tahap pembelajaran ini berada pada kategori kategori baik. Sedangkan untuk indikator tertinggi berada pada indikator kerjasama kelompok yang memiliki persentase $86 \%$ dan berada pada kategori sangat baik.

Berdasarkan hasil analisis, diperoleh persentase rata-rata respon peserta didik sebesar $80 \%$. Data rata-rata respon peserta didik sebesar $80 \%$ memberikan informasi bahwa dengan pembelajaran menggunakan model Project Based Learning (PjBL) peserta didik memiliki respon yang baik. Hal ini dikarenakan di SMAN 1 Muara Pahu, peserta didik jarang untuk menggunakan alat-alat laboratorium dan melakukan percobaan. Sehingga pada saat menggunakan model ini peserta didik diwajiban untuk melakukan percobaan dan peserta didik sangat antusias karenanya. Selain melakukan percobaan, beberapa peserta didik juga membuat sebuah produk. Hal ini juga membuat peserta didik bersemangat untuk menunjukkan kreativitas mereka dalam membuat produk. Walaupun kebanyakan peserta didik mengalami kesulitan pada saat tahap pembelajaran, namun peserta didik masih merasa cukup senang dalam belajar menggunakan model ini.

Hal ini sesuai dengan pendapat Railsbach (dalam Priansa, 2015), yang mengatakan kelebihan Model Project Based Learning ( $\mathrm{PjBL}$ ) dapat meningkatkan rasa percaya diri peserta didik. Selain itu, hasil penelitian Kristanti, Subiki, dan Handayani (2017) yang pada penelitiannya mendapatkan hasil bahwa respon peserta didik terhadap model Project Based Learning (PjBL) berada pada kategori cukup. Hal ini berarti bahwa peserta didik cukup menyukai penggunaan model Project Based Learning $(\mathrm{PjBL})$ dalam pembelajaran fisika.

\section{PENUTUP}

Berdasarkan hasil penelitian dan pembahasan, maka dapat ditarik kesimpulan bahwa aktivitas belajar peserta didik kelas XI IPA di SMAN 1 Muara Pahu pada materi fluida statis berada pada kategori baik atau dapat dikatakan aktif dengan persentase rata-rata aktvitas belajar peserta didik adalah $71 \%$. Hasil belajar kognitif peserta didik kelas XI IPA di SMAN 1 Muara Pahu pada materi fluida statis setelah diberlakukan model Project Based Learning ( $\mathrm{PjBL}$ ) mendapatkan hasil sebanyak 17 orang peserta didik belum tuntas dan sebanyak 14 orang peserta didik tuntas. Respon peserta didik kelas XI IPA di SMAN 1 Muara 
Pengaruh Model Pembelajaran....

Pahu pada materi fluida statis berada pada kategori baik dengan rata-rata respon peserta didik adalah 75,47.

Berdasarkan temuan-temuan yang diperoleh selama penelitian, maka peneliti menyarankan bagi guru sebaiknya dalam proses belajar mengajar khususnya mata pelajaran fisika dapat menggunakan dan melakukan inovasi mengajar dengan menggunakan model Project Based Learning (PjBL). Bagi sekolah, sebaiknya dapat meningkatkan sarana dan prasarana penunjang kegiatan belajar mengajar terutama kipas angin dan kelengkapan alat praktikum. Penulis mengharapkan adanya penelitian lebih lanjut dari peneliti lain mengenai pembelajaran fisika menggunakan mdel Project Based Learning (PjBL) pada materi yang berbeda.

\section{DAFTAR PUSTAKA}

Ali, M. Nur. (2018). Peringkat Pendidikan Indonesia dan Budaya Buruknya. Diakses pada tanggal 13 Juni 2019 dari https://siedoo.com/berita-4965-peringkatpendidikan-indonesia-dan-budayaburuknya/amp

Asmi, S., \& Hasan, M. (2017). Penerapan Model Pembelajaran Berbasis Proyek Pada Materi Suhu Dan Kalor Untuk Meningkatkan Keterampilan Proses. Jurnal Pendidikan Sains Indonesia (Indonesian Journal of Science Education), 5(1), 20-26.

Cahya Abadi, B. (2017). Penerapan Self Directed Learning Berbasis Moodle Untuk Meningkatkan Hasil Belajar Siswa Kelas Xi Teknik Komputer Jaringan. It-Edu, 2(01), 162-170.

Daryanto dan Mulyo. (2013). Inovasi Pembelajaran Efektif. Bandung:Yrama Widya.

Dwi, A., Prihandono, T., \& Subiki. (2017). Pembelajaran Fisika Fluida Statis Dengan Model Project Based Learning Disertai Mind Map Di MAN 1 Jember. Jurnal Pembelajaran Fisika, 7(2), 123-128.

Dwi Ariani, S. R., Addiin, I., \& Redjeki, T. (2014). Penerapan Model Pembelajaran Project Based Learning (Pjbl) Pada Materi Pokok Larutan Asam Dan Basa Di Kelas XI IPA 1
Sma Negeri 2 Karanganyar Tahun Ajaran 2013/2014. Jurnal Pendidikan Kimia Universitas Sebelas Maret, 3(4), 7-16.

Fathurrohman, M. (2016). Model-model Pembelajaran Inovatif. Yogyakarta: ArRuzz Media.

Gunawan, G., Setiawan, A., \& Widyantoro, D. (2013). Model Virtual Laboratory Fisika Modern Untuk Meningkatkan Keterampilan Generik Sains Calon Guru. Jurnal Pendidikan Dan Pembelajaran Universitas Negeri Malang, 20(1), 25-32.

Hanafiah, (2012). Konsep Strategi Pembelajaran. Bandung: Refika Aditama.

Ita, (2019). Potret Pendidikan Indonesia di Tengah Perkembangan Teknologi. Diakses pada tanggal 13 Juni 2019 dari https://news.detik.com/dw/d4533564/potret-pendidikan-indonesia-ditengah-perkembangan-teknologi.html

Karsumi. (2012). Pengembangan Alat Praktikum Viskosimeter Zat Cair. Jurnal Pendidikan Fisika Indonesia, vol 8(1), 8-14.

Kristanti, Y., Subiki, S., \& Handayani, R. (2016). Model Pembelajaran Berbasis Proyek (Project Based Learning Model) Pada Pembelajaran Fisika Disma. Jurnal Pembelajaran Fisika Universitas Jember, 5(2), 116319.

Lawe, Y. U. (2019). Pengaruh Model Pembelajaran Berbasis Proyek Berbantuan Lembar Kerja Siswa Terhadap Hasil Belajar Ipa Siswa Sd. Journal of Education Technology, 2(1), 26. https://doi.org/10.23887/jet.v2i1.13803

Lestari, N. (2019). Penerapan Model Pembelajaran Berbasis Proyek untuk Meningkatkan Aktivitas dan Hasil Belajar Siswa Kelas V SD Ar-Rahman Misriadi Desa Stabat Lama Langkat. Jurnal Pendidikan Dan Pembelajaran Terpadu, 01(01), 13-23. http://jurnalIp2m.umnaw.ac.id/index.php/JPPT/article/vi $\underline{\mathrm{ew} / 345}$

Sudjana, N. (2013). Penilaian Hasil Proses Belajar Mengajar. Bandung: PT. Remaja

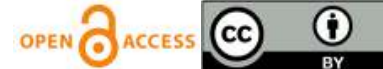


Rosdakarya.

Priansa, D. J. (2015). Manajemen Peserta Didik dan Model Pembelajaran. Bandung; Alfabeta.

Riduwan. (2010). Dasar-dasar statistik. Bandung: Alfabeta.

Sitaresmi, K., Saputro, S., \& Utomo, S. (2017). Penerapan Pembelajaran Project Based Learning (Pjbl) Untuk Meningkatkan Aktivitas Dan Prestasi Belajar Siswa Pada Materi Sistem Periodik Unsur (Spu) Kelas $X$ Mia 1 Sma Negeri 1 Teras Boyolali Tahun Pelajaran 2015/2016. Jurnal Pendidikan Kimia, 6(1), 54-61.

Suastha, R. D. (2016). UNESCO Soroti Kesenjangan Kualitas Pendidikan di Indosesia. Diakses pada tanggal 13 Juni 2019 dari https://www.cnnindonesia.com/nasional/20 160906155806-20-156462/unesco-sorotikesenjangan-kualitas-pendidikan-diindonesia.html

Sugiyono, (2015). Metode Penelitian Pendidikan (Pendekatan, Kuantitatif, Kualitatif, dan $R \& D)$. Bandung: Alfabeta.

Suhana. (2014). Konsep Strategi Pembelajaran. Bandung: PT Refika Aditama.

Trianto. (2012). Mendesain Model Pembelajaran Inovatif Progresif : Konsep Landasan dan Implementasi pada Kurikulum Tingkat Satuan Pendidikan. Jakarta: Kencana.

Ulfa, N. (2015). Pengaruh Model Pembelajaran PBL (Problem Based Learning) Terhadap Hasil Belajar Siswa Pada Materi Bahan Kimia Dalam Kehidupan Sehari-Hari Di Kelas VIII SMPN 1 Sukamakmur. Skripsi tidak dipublikasikan, Universitas Islam Negeri Ar-Raniry.

Wulandari, F. E. (2016). Pengaruh Model Pembelajaran Berbasis Proyek untuk Melatihkan Keterampilan Proses Mahasiswa. PEDAGOGIA: Jurnal Pendidikan, 247. https://doi.org/10.21070/pedagogia.v5i2.25 $\underline{7}$

Yance, R. D., Ramli, E., \& Mufit, F. (2013). Pengaruh Penerapan Model Project Based
Learning ( $\mathrm{Pbl}$ ) Terhadap Hasil Belajar Fisika Siswa Kelas Xi Ipa Sma Negeri 1 Batipuh Kabupaten Tanah Datar. 1(April), 48-54. 